\title{
THE CONCEPT OF METHOD OF DETECTING AND ANALYZING CONSTRUCTION DEFECTS IN RESIDENTIAL BUILDINGS
}

\begin{abstract}
K. ZIMA ${ }^{1}$, S. BIEL ${ }^{2}$
The authors developed the definition of construction defect and fault and construction defect management based on Polish and foreign publications. In order to assist identification of faults and their analysis in the process of home collection, the authors applied the Case Based Reasoning (CBR) method. In the paper, the authors used Case Based Reasoning (CBR) to support acceptance of apartments. The CBR method allows to determine the magnitude of global similarity for the problem under consideration between the new and old case from the Case Base, using weighted sums of local similarities using criteria weights as coefficients. As a result of CBR-based solutions, an Employer's representative receives information about the type of construction defects that can be expected, their location and significance, occurrence frequency, and estimated repair cost.
\end{abstract}

Keywords: construction defects, apartment acceptance, analysis of construction defects, Case Based Reasoning

\section{INTRODUCTION}

The Polish real estate market grows every year - hundreds of thousands of Poles buy apartments on the developer market each year. An increased attention to the apartment quality has been noticeable in recent years. Buyers are willing to pay more or buy a smaller flat in return for other attributes, such as environmentally friendly and energy-saving solutions, transport connections and friendly surrounding of the building, preferred architecture and high-quality materials.

\footnotetext{
${ }^{1}$ Prof., DSc., PhD., Eng., Cracow University of Technology, Faculty of Civil Engineering, Warszawska 24 Street, 31 155 Cracow, Poland, e-mail: kzima@L3.pk.edu.pl

${ }^{2}$ MSc., Eng., Cracow University of Technology, Faculty of Civil Engineering, Warszawska 24 Street, 31-155 Cracow, Poland, e-mail: sbiel@L3.pk.edu.pl
} 
A 184.8 thousand apartments were commissioned from January to December 2018, that is $3.6 \%$ more than the year before. In 2018, developers commissioned 111.6 thousand apartments, $6.2 \%$ more than in 2017 [1]. However, construction defects are found during the acceptance of majority of flats, therefore the authors believe that there is a need to develop solutions that will simplify and improve the apartment acceptance. In addition, the authors intended to develop methods that will facilitate the acceptance management.

The paper presents the use of Case Based Reasoning (CBR) in identification and analysis of construction defects. The aim of the article is to propose a concept of supporting the process of identification and analysis of building defects during the acceptance of flats in residential buildings.

\section{CONSTRUCTION DEFECTS AND FAULTS IN LITERATURE}

There is not generally accepted definition of fault and defect in the polish construction industry. In case of these terms, it seems that a "fault" is something of a larger scale than a "defect", however these terms generally are not differentiated. Other terms are also used in the construction industry, such as shortage, nonconformity, deviation, error.

According to PN-EN ISO 9000:2015 a defect is a "failure to meet a requirement in relation to the intended or specified use", and the requirement is understood as a "need or expectation which has been agreed, accepted customarily or is mandatory" [2].

Each sale contract entails the seller's responsibility towards the buyer. The object of such responsibility is the sold item, and to be more precise - the sale of a defective item. Pursuant to Art. $556 \S 1$ of Civil Code [3] the seller is responsible towards the buyer if the sold item has a defect.

The Civil Code differentiates between two types of defects: physical and legal. The Civil Code defines the physical defect as a nonconformity of the sold item with the contract. An item does not conform to the contract if:

- it does not have the properties that such product should have;

- it does not have the properties that the seller claimed it does;

- is not suitable for the purpose about which the seller informed the buyer;

- has been sold to the buyer in an incomplete state.

Physical defects can include noncompliance with technical and building codes, technical conditions for buildings and their location, state of art, and with basic requirements such as e.g. safety of structure and use, fire safety, etc. [4].

In law, doctrine and court judgements, the physical defects are classified as [4]: 
- patent defects (defects discovered during the final acceptance at the latest);

- major defects (precluding the use of a building, however in particularly justified cases the Building Act allows a deviation from technical and building codes);

- latent defects (defects discovered during the warranty period);

- permanent defects (defects with which a building can be used, however bringing it to the conformity with the contract requires excessive costs);

- insidiously concealed defects (defects about which the contractor knew during the construction works, but failed to inform the Employer about them).

Pursuant to Art. 556 of the Civil Code, a legal defect occurs when the sold item is the property of a third party or is encumbered with third party rights, and also when there are limitations resulting from the decision or ruling of a competent authority in the use or disposal of the item. An example of legal defects is the use of stolen materials in the building, or materials or equipment not approved for use in construction (unless they were delivered by the Employer, and the Contractor has detected that and informed the Employer about it in writing) [4].

The terms of construction defect is not defined precisely, there are no laws that would specify this terms strictly. In Polish literature, an attempt to define the "construction defect" was made by Chrabczyński and Heine [5].

A defect is any unfavourable and unintentional property of a built facility that impedes its use according to purpose or its maintenance or reduces its aesthetics or user comfort, which can be eliminated by means of contemporary construction technology. The defect is not only a property, but also an absence of the facility property about which the seller (=contractor) assured the buyer (=owner).

During the session of California State Assembly, Scott Baugh submitted the bill AB 2959 in which he attempted to define the "construction defect". According to Baugh, the construction defect is that which makes a project dangerous, unsafe or causes real damage to the consumer. A construction defect would result from defective building material or component, violation of Building Codes at the time of construction, failure to meet professional standards for design at the time plans were approved, and failure to build according to accepted trade standards [6].

M. Kraus, T. Vondráčková and V. Nývlt [7] defined the defect as a lack of construction due to incorrect design, inadequate or imperfect execution decreasing performance of structure. The defect is not a change of construction compared to the original state. The fault is temporary or permanent depletion capabilities of construction. The fault is a change of construction compared to the original state. Faults may occur as a cause of the defect. Fault of construction has 
technical consequences. M. Kraus et al. classified the defects based on three categories, relevance, visibility and remediation.

Based on the literature review, the authors decided to develop a definition of construction defect and fault.

Fault is any unfavourable property of a built facility or its absence which is an inadmissible change of or a deviation in comparison to its target state. The defect absolutely must be repaired or the financial liability of the employer towards the contractor must be reduced.

Defect is any unfavourable property of a built facility or its absence that impedes its use according to purpose or its maintenance or reduces its aesthetics or user comfort which does not an inadmissible change in comparison to its target state.

\section{MANAGEMENT OF CONSTRUCTION DEFECTS}

According to R.W. Griffin [8] the management is a set of activities (including planning and decision making, organizing, leading, and controlling) directed at an organization's resources (human, financial, physical, and informational) with the aim of achieving organizational goals in an efficient and effective manner.

There are four basic activities in the management process [8],[9]:

- Planning - setting realistic and achievable goals, and development of action plans and strategies;

- Organizing - determination of the ways of executing the tasks set at the planning stage and reasonable division of available resources between the team members

- Leading - guiding people using various motivation systems;

- Controlling - supervising the organization's actions, verifying the results, comparing the as-state and the planned state, drawing conclusions and making corrections.

The management is a process which directs the organization's actions to achieving its goals in an efficient and effective manner. The effectiveness means executing the previously planned actions as a result of which the goals are achieved. The efficiency is a favourable ratio of used resources to results.

An attempt to standardize the management process at the stage of planning and execution of construction projects was made in [10]. The construction process is characterized by complex and time-consuming tasks and also by capital intensity, hence the approach to management should be comprehensive. The authors determined that the object of management is to use available tools, 
methods and techniques to achieve the set project goals which is to complete the project within the specified time and budget. The achievement of goals is possible as a result of standardization of processes, development of rules and identification of sequences of repeated activities.

Based on the literature review, the authors developed a definition of construction defect management.

Construction defect management can be defined as a set of actions aiming at repairing the construction defects within the specified time and budget; the actions are performed in the following order:

- planning - finding construction defects in a building, setting the planned cost and final repair deadline;

- organizing - assigning the enterprises responsible for repair of construction defects;

- leading - guiding and synchronizing the actions of enterprises in order to keep the deadlines;

- controlling - verification of methods, costs and time of defect repair, controlling the repair correctness by acceptance of the works.

\section{USE OF THE CBR METHOD IN IDENTIFICATION AND ANALYSIS OF CONSTRUCTION DEFECTS}

Knowledge acquisition from cases is related to machine learning. The process involving the knowledge acquisition from previous cases is based on a continuous improvement of knowledge database by means of verifying the data correctness, assimilating and formulating new terms based on examples from the past. Case Based Reasoning (CBR) allows the descriptions of terms to be generated based on examples.

In CBR, the source of knowledge is not rules as in many other machine learning methods, but a database containing cases from previous problems. CBR faithfully imitates human intelligence and learning process because the reasoning system modifies its behaviour based on gathered experience. CBR is a problem-solving method which involves searching for analogies between the current situation and previous cases whose components are appropriately described in databases [11]. CBR can be defined as systems that solve new problems by adapting the results which were used to solve old problems [12].

A simplified cased based reasoning process is presented in Fig. 1. 


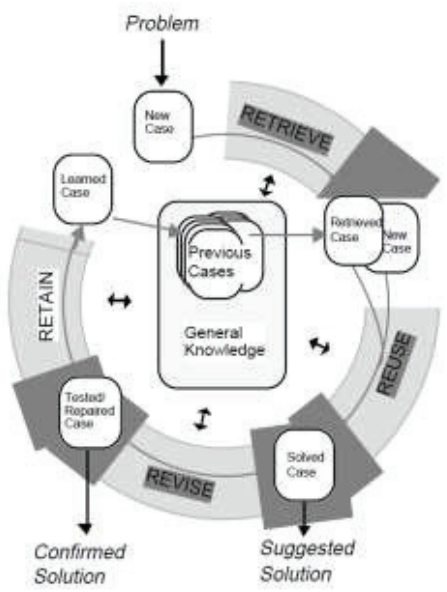

Fig. 1 The CBR cycle

Source: [13]

The operation of CBR-based systems can be described using four R's:

- Retrieve from the Case Base a case or cases most similar to the new problem;

- Reuse the most similar case;

- Revise the obtained solution. The proposed solution is tested or evaluated. Sometimes the old solution does not match the new case perfectly (e.g. similarity between cases is less than 100\%). The solution needs to be adapted then to meet the expectations.

- Retain the new solution in the database (Case Base). The aim is to obtain useful cases by adding new situations and solutions, resulting in an incremental learning process.

\section{USE OF THE CBR METHOD IN IDENTIFICATION AND ANALYSIS OF CONSTRUCTION DEFECTS}

The purpose of measurement is to determine the total similarity for the examined problem between two cases - the new case (examined case), and the old case (previous). A simple and reliable method to achieve it is the application of weighted sums of local similarities, using criteria weights as coefficients [14]. For individual cases described by $n$ attributes:

- for new case $x=\left(x_{1}, x_{2}, \ldots, x_{n}\right)$,

- for old case $y=\left(y_{1}, y_{2}, \ldots, y_{n}\right)$. 
determined are local similarities $\operatorname{sim}_{1}\left(x_{1}, y_{1}\right), \operatorname{sim}_{2}\left(x_{2}, y_{2}\right), \ldots, \operatorname{sim}_{n}\left(x_{n}, y_{n}\right)$. Then, the global similarity $\operatorname{SIM}(x, y)$ is calculated using the local similarities with appropriate attribute weights $\omega_{\mathrm{i}}$. Two types of similarity function are presented in literature [15]:

- absolute similarity function - a function that returns two logical (Boolean) values (true of false) and is used only to determine whether two objects are similar or not $\mathrm{s}(i, j) \rightarrow\{$ True; False\},

- relative similarity function - a function that determines the strength of relationship between two objects $s(i, j) \rightarrow[0,1]$ and satisfies the following conditions for all objects $i, j$ :

$\circ \quad 0 \leq \mathrm{s}(i, j) \leq 1$,

○ $\mathrm{s}(i, j)=1$, when and only when $\mathrm{i}$ and $\mathrm{j}$ are identical,

○ $\mathrm{s}(i, j)=\mathrm{s}(j, i)$.

The CBR method allows a much more flexible approach to the problem compared to statistical methods. Statistical methods allow to find identical cases, and then a list of possible construction defects will be generated for them. The CBR method determines that the collection belongs to a certain similarity, therefore the resulting construction defects list should be more accurate and reflect reality more accurately.

The first stage of Case Based Reasoning (CBR) is to find a case or cases closest to the new problem from all cases collected in the case base.

The presented case base comprises 831 items representing identified construction defects in the apartments undergoing acceptance. A fragment of case base is presented in Table 1. Each case in the base, and also the new case, is described by means of seven criteria:

\section{- Apartment type}

Qualitative criterion. It includes 66 apartment types and takes into account apartment shape, construction technology and cardinal directions. During further research the criterion will be made more detailed and divided to sub-criteria, as a result of which the number of apartment types will be aggregated.

\section{- Number of rooms}

Quantitative criterion describing the number of rooms in an apartment. There are 1,2,3,4 and 5-room apartments in the database.

\section{- Floorage}

Quantitative criterion. The database includes 172 apartments, from $29.01 \mathrm{~m}^{2}$ to $116.95 \mathrm{~m}^{2}$. 


\section{- Room code (function)}

Qualitative criterion that defines the function of a room in an apartment. The database includes 17 room types, amongst others anteroom (1), hall (1a), kitchen (2), room with kitchenette (3), day room (4), bedrooms (5-8), bathroom (9), toilet (10), walk-in closet (11), pantry (12), balcony (13), terrace (14), loggia (15), garden (17), mezzanine (16).

\section{- Room size}

Quantitative criterion. The database includes 1196 rooms with floorage ranging from 1.36 to $56.05 \mathrm{~m}^{2}$.

\section{- Storey}

Quantitative criterion describing the storey on which an apartment is located. There are 16 storeys in the database, from the ground floor to the $15^{\text {th }}$ floor.

\section{- Occupant-made modifications}

Qualitative criterion that allows searching for apartments in which occupants have or have not made modifications.

Table 1. A fragment of case base of identified construction defects

\begin{tabular}{|c|c|c|c|c|c|c|c|c|c|c|c|}
\hline Case number & 1 & $\ldots$ & 8 & $\ldots$ & 93 & $\ldots$ & 154 & $\ldots$ & 191 & $\ldots$ & 831 \\
\hline Apartment / Room & $1 / 1$ & $\ldots$ & $2 / 4$ & $\ldots$ & $20 / 4$ & $\ldots$ & $30 / 4$ & $\ldots$ & $37 / 9$ & $\ldots$ & $172 / 16$ \\
\hline Apartment type & $\mathrm{A}$ & $\ldots$ & $\mathrm{B}$ & $\ldots$ & $\mathrm{B}$ & $\ldots$ & $\mathrm{F} 1$ & $\ldots$ & $\mathrm{H} 1$ & $\ldots$ & An4 \\
\hline Number of rooms & 1 & $\ldots$ & 2 & $\ldots$ & 2 & $\ldots$ & 3 & $\ldots$ & 4 & $\ldots$ & 2 \\
\hline Floorage [m2] & 30,89 & $\ldots$ & 49,98 & $\ldots$ & 49,98 & $\ldots$ & 61,71 & $\ldots$ & 83,91 & $\ldots$ & 40,19 \\
\hline Room code & 1 & $\ldots$ & 4 & $\ldots$ & 4 & $\ldots$ & 4 & $\ldots$ & 9 & $\ldots$ & 16 \\
\hline Room size [m2] & 5,2 & $\ldots$ & 17,35 & $\ldots$ & 17,35 & $\ldots$ & 16,37 & $\ldots$ & 3,85 & $\ldots$ & 35,97 \\
\hline Storey & 1 & $\ldots$ & 1 & $\ldots$ & 4 & $\ldots$ & 5 & $\ldots$ & 7 & $\ldots$ & 15 \\
\hline $\begin{array}{c}\text { Occupant-made modifications } \\
{[\text { Yes/No] }}\end{array}$ & No & $\ldots$ & No & $\ldots$ & No & $\ldots$ & No & $\ldots$ & No & $\ldots$ & No \\
\hline
\end{tabular}

The issues of construction defects were studied by E. Plebankiewicz, K. Zima, J. Malara and S. Biel. In [16] the authors analysed construction defects - their number, and also elements and rooms in which they are located, and proposed a proprietary method of apartment acceptance, while in [17] the authors estimated an average repair cost of defects found during acceptance.

In the calculation example, the new case is a $18.4 \mathrm{~m}^{2}$ day room in a type $\mathrm{B}, 52.00 \mathrm{~m}^{2}$, 2-room apartment. The apartment is on the $1^{\text {st }}$ floor and has no occupant-made modifications.

In order to find similar cases in the base, it is necessary to determine the total similarity for the examined problem between two cases - the new case (examined case), and the old case (previous), 
by calculating local similarities $\operatorname{sim}_{1}\left(x_{1}, y_{1}\right), \operatorname{sim}_{2}\left(x_{2}, y_{2}\right), \ldots, \operatorname{sim}_{\mathrm{n}}\left(x_{n}, y_{n}\right)$. Then, the global similarity $\operatorname{SIM}(x, y)$ is calculated using the local similarities with appropriate attribute weights $\omega_{\mathrm{i}}$ :

$$
\operatorname{SIM}(x, y)=\sum_{i=1}^{n} \omega_{i} \operatorname{sim}_{i}\left(x_{i}, y_{i}\right)
$$

where:

$\operatorname{SIM}(x, y)-$ global similarity between case $x$ and case $y, \operatorname{sim}_{\mathrm{i}}(\mathrm{x}, \mathrm{y})-$ local similarity between variables $x_{i}$ and $y_{i}, \omega_{\mathrm{i}}-$ weight of $\mathrm{i}$-th local similarity.

Local similarity $\operatorname{sim}_{\mathrm{i}}(\mathrm{x}, \mathrm{y})$ of the new and old case can be calculated with the use of various formulas depending on the criterion types. The formulas used in the algorithm are presented below:

- Similarity of quantitative attributes

$$
\operatorname{sim}\left(w_{n}, w_{j}\right)=1-\frac{\left|w_{n}-w_{j}\right|}{w_{\max }-w_{\min }}
$$

where:

$w_{n}$ - value of the explanatory variable for the new case, $w_{j}$ - value of the explanatory variable for the $j$-th old case, $\mathrm{w}_{\max }, \mathrm{w}_{\min }$ - minimum and maximum values for all the old cases included in the database

- Similarity of qualitative attributes

$$
\operatorname{sim}\left(w_{n}, w_{j}\right)=1-\frac{\left|n\left(w_{n}\right)-n\left(w_{j}\right)\right|}{M-1}
$$

where:

$n\left(w_{n}\right)-n\left(w_{j}\right)$ - place in an ordered array of values $(n(w)=1,2, \ldots, n), M-$ number of values

Table 2 presents the results of calculations with the use of formulas shown earlier: 
Table 2. Calculation of local and global similarities

\begin{tabular}{|c|c|c|c|c|c|c|c|c|c|c|c|}
\hline Case number & $\mathbf{1}$ & $\ldots$ & $\mathbf{8}$ & $\ldots$ & $\mathbf{9 3}$ & $\ldots$ & $\mathbf{1 5 4}$ & $\ldots$ & $\mathbf{1 9 1}$ & $\ldots$ & $\mathbf{8 3 1}$ \\
\hline Apartament / Room & $1 / 1$ & $\ldots$ & $2 / 4$ & $\ldots$ & $20 / 4$ & $\ldots$ & $30 / 4$ & $\ldots$ & $37 / 9$ & $\ldots$ & $172 / 16$ \\
\hline Apartment type & $\mathrm{A}$ & $\ldots$ & $\mathrm{B}$ & $\ldots$ & $\mathrm{B}$ & $\ldots$ & $\mathrm{F} 1$ & $\ldots$ & $\mathrm{H} 1$ & $\ldots$ & An4 \\
\hline Number of rooms & 1 & $\ldots$ & 2 & $\ldots$ & 2 & $\ldots$ & 3 & $\ldots$ & 4 & $\ldots$ & 2 \\
\hline Floorage $\left[\mathrm{m}^{2}\right]$ & 30,89 & $\ldots$ & 49,98 & $\ldots$ & 49,98 & $\ldots$ & 61,71 & $\ldots$ & 83,91 & $\ldots$ & 40,19 \\
\hline Room code & 1 & $\ldots$ & 4 & $\ldots$ & 4 & $\ldots$ & 4 & $\ldots$ & 9 & $\ldots$ & 16 \\
\hline Room size $\left[\mathrm{m}^{2}\right]$ & 5,2 & $\ldots$ & 17,35 & $\ldots$ & 17,35 & $\ldots$ & 16,37 & $\ldots$ & 3,85 & $\ldots$ & 35,97 \\
\hline Storey & 1 & $\ldots$ & 1 & $\ldots$ & 4 & $\ldots$ & 5 & $\ldots$ & 7 & $\ldots$ & 15 \\
\hline Lccupant-made modifications & No & $\ldots$ & No & $\ldots$ & No & $\ldots$ & No & $\ldots$ & No & $\ldots$ & No \\
\hline Lecal similarities for each case and criteria & & & \\
\hline Apartment type & 0,00 & $\ldots$ & 1,00 & $\ldots$ & 1,00 & $\ldots$ & 0,00 & $\ldots$ & 0,00 & $\ldots$ & 0,00 \\
\hline Number of rooms & 0,75 & $\ldots$ & 1,00 & $\ldots$ & 1,00 & $\ldots$ & 0,75 & $\ldots$ & 0,50 & $\ldots$ & 1,00 \\
\hline Floorage & 0,76 & $\ldots$ & 0,98 & $\ldots$ & 0,98 & $\ldots$ & 0,89 & $\ldots$ & 0,64 & $\ldots$ & 0,87 \\
\hline Room code & 0,00 & $\ldots$ & 1,00 & $\ldots$ & 1,00 & $\ldots$ & 1,00 & $\ldots$ & 0,00 & $\ldots$ & 0,00 \\
\hline Room size & 0,76 & $\ldots$ & 0,98 & $\ldots$ & 0,98 & $\ldots$ & 0,96 & $\ldots$ & 0,73 & $\ldots$ & 0,68 \\
\hline Storey & 1,00 & $\ldots$ & 1,00 & $\ldots$ & 0,79 & $\ldots$ & 0,71 & $\ldots$ & 0,57 & $\ldots$ & 0,00 \\
\hline Global similarities for each case & & \\
\hline
\end{tabular}

Case Based Reasoning was applied to find and select the cases with global similarity greater than 95\% (Table 3).

Table 3. Similar cases

\begin{tabular}{|c|c|c|c|c|}
\hline Case number & 8 & 39 & 93 & 130 \\
\hline Apartament / Room & $2 / 4$ & $8 / 4$ & $20 / 4$ & $26 / 4$ \\
\hline Apartment type & $\mathrm{B}$ & $\mathrm{B}$ & $\mathrm{B}$ & $\mathrm{B}$ \\
\hline Number of rooms & 2 & 2 & 2 & 2 \\
\hline Floorage $\left[\mathrm{m}^{2}\right]$ & 49,98 & 49,98 & 49,98 & 49,98 \\
\hline Room code & 4 & 4 & 4 & 4 \\
\hline Room size $\left[\mathrm{m}^{2}\right]$ & 17,35 & 17,35 & 17,35 & 17,35 \\
\hline Storey & 1 & 2 & 4 & 5 \\
\hline Occupant-made modifications [Yes/No] & No & No & No & No \\
\hline Case number & 8 & 39 & 93 & 130 \\
\hline Apartment type & 1,00 & 1,00 & 1,00 & 1,00 \\
\hline Number of rooms & 1,00 & 1,00 & 1,00 & 1,00 \\
\hline Floorage $\left[\mathrm{m}^{2}\right]$ & 0,98 & 0,98 & 0,98 & 0,98 \\
\hline Room code & 1,00 & 1,00 & 1,00 & 1,00 \\
\hline Room size $\left[\mathrm{m}^{2}\right]$ & 0,98 & 0,98 & 0,98 & 0,98 \\
\hline Storey & 1,00 & 0,93 & 0,79 & 0,71 \\
\hline Occupant-made modifications [Yes/No] & 1,00 & 1,00 & 1,00 & 1,00 \\
\hline Global similarities & 0,99 & 0,98 & 0,96 & 0,95 \\
\hline
\end{tabular}

On the other hand, based on the construction defect database, it can be said that in cases $8,39,93$ and 130 the following construction defects were found: (Table 4). 
Table 4. Construction defect found in similar cases

\begin{tabular}{|c|c|c|c|c|c|}
\hline $\begin{array}{l}\text { Apartament } \\
\text { number }\end{array}$ & Description & Defect group & Object & $\begin{array}{c}\text { Defect } \\
\text { significance }\end{array}$ & $\begin{array}{l}\text { Estimated defect } \\
\text { repair cost }\end{array}$ \\
\hline \multicolumn{6}{|c|}{ Case no. 8} \\
\hline 2 & $\begin{array}{l}\text { Scratched window } \\
\text { sill }\end{array}$ & Scratched window sill & Window sill & Low & 14.63 \\
\hline 2 & Cracked screed & Cracked screed & Floor & High & 86.42 \\
\hline 2 & Cracked screed & Cracked screed & Floor & High & 86.42 \\
\hline 2 & Cracked screed & Cracked screed & Floor & High & 86.42 \\
\hline 2 & Cracked screed & Cracked screed & Floor & High & 86.42 \\
\hline \multicolumn{6}{|c|}{ Case no. 39} \\
\hline 8 & Scratched window & $\begin{array}{l}\text { Scratched window } \\
\text { panel }\end{array}$ & Window & Medium & 10.97 \\
\hline 8 & $\begin{array}{l}\text { Chips in walls (to } \\
\text { be patched) }\end{array}$ & $\begin{array}{l}\text { Chips to be patched } \\
\text { (Wall) }\end{array}$ & Wall & Medium & 10.46 \\
\hline \multicolumn{6}{|c|}{ Case no. 93} \\
\hline 20 & Rubbish & Rubbish & Floor & Low & 18.28 \\
\hline 20 & $\begin{array}{c}\text { Dirty balcony door } \\
\text { leaf }\end{array}$ & Dirty joinery & $\begin{array}{l}\text { Balcony } \\
\text { door }\end{array}$ & Low & 36.55 \\
\hline 20 & Scratched walls & Scratches & Wall & High & 15.64 \\
\hline 20 & $\begin{array}{l}\text { Scratched window } \\
\text { sill }\end{array}$ & Scratched window sill & Window sill & Low & 14.63 \\
\hline 20 & $\begin{array}{c}\text { Scratched external } \\
\text { window sill }\end{array}$ & Scratched window sill & Window sill & Low & 14.63 \\
\hline 20 & Scratched window & $\begin{array}{l}\text { Scratched window } \\
\text { panel }\end{array}$ & Window & Medium & 10.97 \\
\hline \multicolumn{6}{|c|}{ Case no. 130} \\
\hline 26 & Scratched window & $\begin{array}{c}\text { Scratched window } \\
\text { panel }\end{array}$ & Window & Medium & 10.97 \\
\hline 26 & $\begin{array}{c}\text { Dirty window } \\
\text { handle }\end{array}$ & Dirty handle & Window & Low & 7.31 \\
\hline 26 & Scratched window & $\begin{array}{c}\text { Scratched window } \\
\text { panel }\end{array}$ & Window & Medium & 10.97 \\
\hline
\end{tabular}

Based on the data, we can infer that in the new case we can expect the following construction defects (Table 5):

Table 5. Occurrence frequency of construction defects in similar cases

\begin{tabular}{|c|c|c|c|c|c|}
\hline Description & Defect group & Object & $\begin{array}{c}\text { Defect } \\
\text { significance }\end{array}$ & $\begin{array}{c}\text { Estimated } \\
\text { defect } \\
\text { repair cost }\end{array}$ & $\begin{array}{c}\text { Occurrence } \\
\text { frequency }\end{array}$ \\
\hline Scratched window & $\begin{array}{c}\text { Scratched window } \\
\text { panel }\end{array}$ & Window & Medium & 10.97 & 0.75 \\
\hline $\begin{array}{c}\text { Scratched window } \\
\text { sill }\end{array}$ & $\begin{array}{c}\text { Scratched window } \\
\text { sill }\end{array}$ & Window sill & Low & 14.63 & 0.50 \\
\hline Cracked screed & Cracked screed & Floor & High & 86.42 & 0.25 \\
\hline
\end{tabular}




\begin{tabular}{|c|c|c|c|c|c|}
\hline Scratched walls & Scratches & Wall & High & 15.64 & 0.25 \\
\hline $\begin{array}{c}\text { Chips in walls (to be } \\
\text { patched) }\end{array}$ & $\begin{array}{c}\text { Chips to be patched } \\
\text { (Wall) }\end{array}$ & Wall & Medium & 10.46 & 0.25 \\
\hline $\begin{array}{c}\text { Dirty balcony door } \\
\text { leaf }\end{array}$ & Dirty joinery & Balcony door & Low & 36.55 & 0.25 \\
\hline Rubbish & Rubbish & Floor & Low & 18.28 & 0.25 \\
\hline Dirty window handle & Dirty handle & Window & Low & 7.31 & 0.25 \\
\hline
\end{tabular}

\section{SUMMARY AND CONCLUSIONS}

The calculations indicate that in rooms similar to the analysed cases, an Employer's representative should expect mainly scratched windows and sills so they should particular attention to windows and sills. In addition, they should pay attention to possible cracked screed, scratched or chipped walls.

The Case Base shows that the type of found construction defects depends on many parameters, inter alia shape, arrangement, size and apartment construction technology, as well the size and function of rooms. The developed tools account for many criteria, hence they are very versatile and can increase the defect detection rate during the acceptance of apartments.

As a result of CBR-based solutions, an Employer's representative receives information about the type of construction defects that can be expected, their location and significance, occurrence frequency, and estimated repair cost. The developed method indicates the objects most prone to construction defects, so during the apartment acceptance the representative should pay particular attention to these areas, and also should look closely at other apartment elements because there may be construction defects that are not included in the Case Base. After the acceptance, the representative should add the new apartment and defects found to the Case Base. This will develop the database, and the information about the defects that can be expected during further acceptance will be more accurate.

The proposed solutions are intended mainly for Employer's representatives. Using these solutions, the representatives will be able to find potential construction defects more easily, they will be able to estimate the repair costs, and the repair time which will be dealt with in further publications. In addition, the proposed solutions can be used also by construction contractors - the cost information will allow estimating the repair costs, and the repair time information will facilitate time management and assigning human resources to repair individual defects. 


\section{REFERENCES}

1. Główny Urząd Statystyczny, "Budownictwo mieszkaniowe w okresie styczeń-grudzień 2018 roku" https://stat.gov.pl/obszary-tematyczne/przemysl-budownictwo-srodki-trwale/budownictwo/budownictwomieszkaniowe-w-okresie-styczen-grudzien-2018-roku,5,86.html.

2. PN-EN ISO 9000: 2015 Ouality management systems - Fundamentals and vocabulary, Poland, 2015.

3. Dz. U. 1964 No. 16 pos. 93 with later changes, Civil Code, Poland, 2019.

4. H. J. Orłowski, "Wady (usterki, niedoróbki) w robotach budowlanych", Buduj z głową - poradnik kosztorysanta. https://www.bzg.pl/node/1668.

5. G. Chrabczyński, A. Heine, “Definicja wady budowlanej”, Inżynier Budownictwa 3(24): 10-11, 2006

6. M. S. Poles, "What Are Construction Defects?" https://www.mpgroup.com/articles/what-are-constructiondefects/

7. M. Kraus, T. Vondráčková, V. Nývlt, "Defects, faults and accidents of contemporary constructions”, MATEC Web of Conferences 93: 03004, 2017.

8. R. W. Griffin, "Podstawy zarządzania organizacjami”, Wydawnictwo Naukowe PWN, Warsaw, Poland, 2017.

9. S. P. Robbins, D.A. DeCenzo, "Podstawy zarządzania", Polskie Wydawnictwo Ekonomiczne, Warsaw, Poland, 2002

10. O. Kapliński, A. Dziadosz, J. L. Zioberski, "Próba standaryzacji procesu zarządzania na etapie planowania i realizacji przedsięwzięć budowlanych”, Zeszyty Naukowe Politechniki Rzeszowskiej, Budownictwo i Inżynieria Środowiska 58(3), 2011.

11. A. Radziejowska, K. Zima, "The concept of a knowledge base to aid in cost estimating of sports facilities", International Journal of Contemporary Management 14(3), 2016.

12. C. K. Riesbeck, R. C. Schank, "Inside Case-based Reasoning", L. Erlbaum Associates Inc., Hillsdale, NJ, USA, 1989.

13. A. Aamodt, E. Plaza, "Case-Based Reasoning: Foundational Issues, Methodological Variations, and System Approaches”, AI Communications 7(1): 39-59, 1994.

14. M. Richter, R. Weber, "Case-based reasoning: a textbook", Springer-Verlag Berlin Heidelberg, Berlin, Germany, 2013.

15. D. G. Bridge, "Defining and combining symmetric and asymmetric similarity measures, Advances in CaseBased Reasoning". Proceedings of the 4th European Workshop on Advances in Case-Based Reasoning EWCBR '98, Dublin, Ireland, Vol. 1448: 52-63, 1998.

16. E. Plebankiewicz, K. Zima, J. Malara, S. Biel, "A procedure of repairing housing defects in development investments", MATEC Web of Conferences 262: 07010, 2019

17. E. Plebankiewicz, K. Zima, J. Malara, S. Biel, "Analiza statystyczna usterek w budynkach mieszkalnych", Materiały Budowlane 1(10): 43-46, 2018.

\section{LIST OF THE FIGURES AND TABLES}

Fig. 1 The CBR cycle

Rys. 1. Cykl działania CBR

Tab. 1. A fragment of case base of identified construction defects

Tab. 1. Fragment bazy przypadków zidentyfikowanych usterek budowlanych

Tab. 2. Calculation of local and global similarities

Tab. 2. Obliczenia podobieństw lokalnych i globalnych

Tab. 3. Similar cases

Tab. 3. Podobne przypadki

Tab. 4. Construction defect found in similar cases 
Tab. 4. Usterki budowlane, wykryte w podobnych przypadkach

Tab. 5. Occurrence frequency of construction defects in similar cases

Tab. 5. Częstość wystąpienia usterek budowlanych w podobnych przypadkach

\section{KONCEPCJA METODY WYKRYWANIA I ANALIZY USTEREK BUDOWLANYCH W WIELORODZINNYCH BUDYNKACH MIESZKALNYCH}

Slowa kluczowe: usterki budowlane, odbiór mieszkań, analiza usterek budowlanych, wnioskowanie z przypadków

\section{STRESZCZENIE:}

\section{Wstęp}

Autorzy opracowali definicję wady, usterki budowlanej oraz zarządzania usterkami budowlanymi na podstawie krajowych i zagranicznych publikacji. W celu wspomagania identyfikacji usterek i ich analizy w procesie odbiorów mieszkań autorzy zastosowali metodę wnioskowania z przypadków (CBR - Case Based Reasoning). Metoda CBR pozwala na wyznaczenie wielkości podobieństwa globalnego dla rozpatrywanego problemu pomiędzy nowym, a starym przypadkiem z Bazy Przypadków, za pomocą ważonych sum lokalnych podobieństw z wykorzystaniem wag kryteriów jako współczynników. Celem artykułu jest zaproponowanie koncepcji wspomagania pracy inspektora nadzoru inwestorskiego podczas identyfikacji i analizy usterek budowlanych w trakcie odbiorów mieszkań w budynkach mieszkalnych wielorodzinnych.

\section{Definicje}

Na podstawie studium literatury, autorzy artykułu postanowili opracować definicję wady i usterki budowlanej.

Wadą jest każda niekorzystna właściwość wybudowanego obiektu lub jej brak, która jest niedopuszczalną zmianą lub odchyleniem w porównaniu do jej docelowego stanu. Wada musi zostać bezwzględnie naprawiona lub powinna zostać zmniejszona należność finansowa inwestora względem wykonawcy.

Usterką budowlaną (in. defektem budowlanym) jest każda niekorzystna właściwość obiektu budowlanego lub jej brak, utrudniająca zgodne $\mathrm{z}$ przeznaczeniem korzystanie $\mathrm{z}$ niego lub obniżająca jego estetykę albo komfort użytkowników, która nie jest niedopuszczalną zmianą w porównaniu do jej docelowego stanu.

\section{Wykorzystanie metody CBR do wykrywania i analizy usterek budowlanych}

Metoda CBR pozwala na wyznaczenie całkowitego podobieństwa dla rozpatrywanego problemu między dwoma przypadkami - nowym (rozpatrywanym), a starym (zaistniałym). Prostym i wiarygodnym sposobem, aby to zrobić jest użycie ważonych sum lokalnych podobieństw za pomocą wag jako współczynników. Dla poszczególnych przypadków opisywanych przez 7 kryteriów autorzy wyznaczyli podobieństwa lokalne $\operatorname{sim}_{1}\left(x_{1}, y_{1}\right), \operatorname{sim}_{2}\left(x_{2}, y_{2}\right), \ldots, \operatorname{sim}_{\mathrm{n}}\left(x_{n}, y_{n}\right)$. Następnie obliczono podobieństwo globalne $\operatorname{SIM}(x, y)$ wykorzystując policzone podobieństwa lokalne $\mathrm{z}$ właściwymi wagami kryteriów $\omega_{\mathrm{i}}$.

Baza przypadków, która posłużyła do obliczeń, składa się z 831 pozycji, reprezentujących zidentyfikowane usterki budowlane w odbieranych mieszkaniach. Każdy przypadek znajdujący się w bazie przypadków został opisany za pomocą siedmiu kryteriów: typ mieszkania, liczba pokoi, powierzchnia mieszkania, kod pomieszczenia, wielkość pomieszczenia, piętro, zmiany lokatorskie. 
W prezentowanym w artykule przykładzie obliczeniowym nowym przypadkiem jest pokój dzienny o wielkości $18,4 \mathrm{~m}^{2}$. Pokój ten został zlokalizowany na 1 piętrze w 2-pokojowym mieszkaniu typu B o powierzchni $52,00 \mathrm{~m}^{2}$. W mieszkaniu nie było żadnych zmian lokatorskich.

\section{Wnioski i podsumowanie}

Na postawie wykonanych obliczeń, można zauważyć, że w pomieszczeniach podobnych do analizowanego przypadku, inspektor nadzoru inwestorskiego powinien spodziewać się głównie porysowanych okien i parapetów, więc powinien zwrócić szczególną uwagę na okna i parapety. Dodatkowo powinien zwrócić uwagę czy nie ma pękniętych wylewek, czy ściany nie są zarysowane, ani czy nie ma na nich żadnych ubytków, które można wyszpachlować.

Dzięki rozwiązaniom opracowanym na podstawie metody CBR, inspektor nadzoru inwestorskiego otrzymuje informacje jakich usterek budowlanych powinien się spodziewać podczas odbioru mieszkania, jaka jest ich lokalizacja, istotność, częstość występowania oraz szacowany koszt ich napraw. Dodatkowo z zaproponowanych rozwiązań będzie mógł skorzystać także wykonawca robót budowlanych - dzięki informacji o koszcie będzie mógł oszacować jakie środki będzie musiał przeznaczyć na naprawę usterek, a informacja o czasie naprawy ułatwi wykonawcy zarządzanie czasem i przydziałem zasobów ludzkich do napraw poszczególnych usterek.

Received 07.09.2019

Revised 04.11.2019 